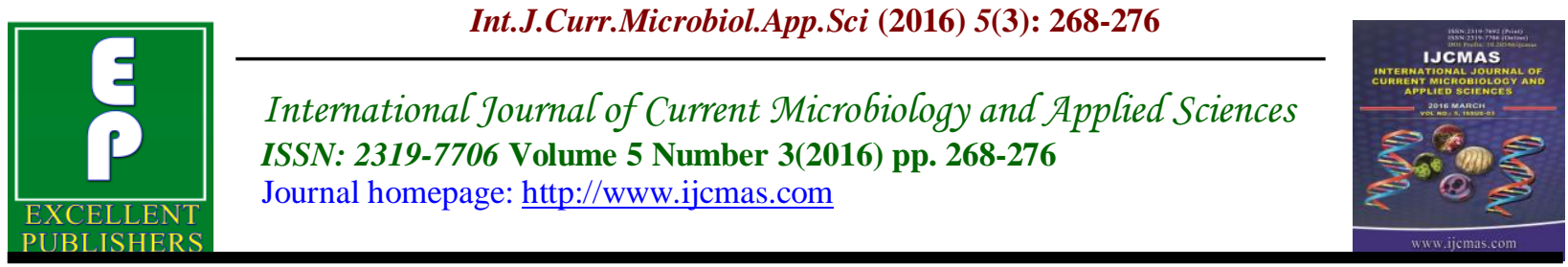

Original Research Article

http://dx.doi.org/10.20546/ijcmas.2016.503.033

\title{
Extraction and Bio-chemical Characterization of Protease Enzyme from a Proteolytic bacteria Isolated from Dry Mixed Kitchen Waste
}

\author{
Diptendu Sarkar $^{1 *}$ and Goutam Paul ${ }^{2}$ \\ ${ }^{1}$ New Horizon College of Engineering, Dept. of Biotechnology, Ring Rd, Kadubisanahalli, \\ Bellandur Post, Near Marathalli, Bangalore-560103, India \\ ${ }^{2}$ Dept. of Physiology, Environmental Physiology Division, Microbiology Unit, \\ University of Kalyani, Nadia, West Bengal-741235, India \\ *Corresponding author
}

\begin{tabular}{|c|c|}
\hline & A B S T R A C T \\
\hline $\begin{array}{l}\text { Key w o r d s } \\
\text { Submerged } \\
\text { Fermentation, } \\
\text { Proteolytic } \\
\text { Activity, } \\
\text { Protease. } \\
\text { Article Info }\end{array}$ & $\begin{array}{l}\text { The present research finding have shown that isolation and biochemical } \\
\text { characterization of protease enzyme from proteolytic bacteria isolated from mixed } \\
\text { vegetable kitchen waste. Three bacterium were isolated from kitchen waste and } \\
\text { were screened for proteolytic enzyme production when grown on protein } \\
\text { containing solid media, and designated them as DSP1, DSP2 and DSP3. DSP2 } \\
\text { (found as Bacillus } s p \text { ) was selected based on clearance zones and protease enzyme }\end{array}$ \\
\hline $\begin{array}{l}\text { Accepted: } \\
\text { 15 February } 2016 \\
\text { Available Online: } \\
\text { 10, March } 2016\end{array}$ & $\begin{array}{l}\text { production was was higher at pH } 6.0 \text { and a temperature of } 30^{\circ} \mathrm{C} \text { using sucrose and } \\
\text { ammonium sulphate as carbon source and nitrogen source, respectively. The } \\
\text { maximal activity of DSP } 2 \text { protease was at } 30^{\circ} \mathrm{C}, \mathrm{pH} 5.0 \text { and was thermostable up to } \\
60^{\circ} \mathrm{C} \text {. Manganese sulphate had high effect on protease enzyme activity. }\end{array}$ \\
\hline
\end{tabular}

\section{Introduction}

Protease is a group of enzymes that break down the complex protein into amino acids. Proteases of commercial importance are produced from microbial, animal and plant sources (Gupta et al., 2005). Microbial proteases are produced from high yielding strains including species of Bacillus sp., Alcaligenes faecalis, Pseudomonas fluorescens and Aeromonas hydrophylia grown under submerged culture conditions. Among these, Bacillus sp. is the most important group of bacteria that are involved in the enzyme industry and this bacterium is also known to produce proteolytic enzymes quite effectively. Moreover, these enzymes are essential in the decay of dead plant material by nonpathogenic microorganisms and thus assist in recycling carbon compounds in the biosphere (Moon et al., 1991; Micales, J.A., 1992). Several literature indicates that enzymes such as protease can be easily extracted from vegetable waste like beet, carrot, cabbage, tomatoes, by simple extraction processes. New enzymes for use in commercial applications with desirable biochemical and physico-chemical characteristics and a low cost production have been the focus of much research. 
Enzyme breakdown of the biomolecules depends upon the type of enzyme, application, temperature, incubation time, agitation, concentration, $\mathrm{pH}$ and use of different enzyme preparations (Patel et al., 1985).

In this context, the objective of the present study was to utilize the kitchen waste and bacterial isolates were extracted, that produce protease enzyme at a cheaper rate. These protease enzymes have importance in industries like fruit industry, textile industry, in waste water treatment and therefore have shown future utility.

\section{Materials and Methods}

\section{Culture Isolation}

Approximately $1.5 \mathrm{~kg}$ of kitchen mixed vegetable waste collected from boy's hostel kitchen of Acharya College of Science, Bangalore and $500 \mathrm{~g}$ of it used to make suspension in $50 \mathrm{ml} \mathrm{D} / \mathrm{W}$. From this suspension, $1 \mathrm{ml}$ was dispensed in $100 \mathrm{ml}$ Nutrient Broth (NB) \& Potato Dextrose Broth (PDB) respectively. The flasks were incubated at shaker conditions of $400 \mathrm{rpm}$ for $48 \mathrm{hr}$ at $30^{\circ} \mathrm{C}$. After incubation, one loopful of suspended broth was inoculated onto Nutrient Agar (NA) and Potato Dextrose Agar (PDA) and incubated at $30^{\circ} \mathrm{C}$ for 48hrs (Kaur et al., 1998).

\section{Screening of Isolates}

Colonies that were grown on NA and PDA media were picked up and spotted on plates containing Hankins's agar medium (HiMedia). These plates were incubated at $30^{\circ} \mathrm{C}$ for $48 \mathrm{hrs}$. After incubation $1 \%$ BSA was overlaid on these plates and kept for half an hour. Clear zones were observed around the colonies indicating the presence of pectinase producing organisms. Cells from these colonies were then picked up and sub- cultured on NA slants and maintained for further studies. Cultures showing larger zones of clearance were chosen for identification based on morphology and biochemical characteristics as per mentioned in Bergy's Manual (Gupta et al., 2005; Fermor et al., 1981).

\section{Preparation of Inoculum}

The Hankins broth medium was prepared in $500 \mathrm{ml}$ Erlenmeyer flasks and the flask was inoculated with loopful of cells grown for $48 \mathrm{hr}$ on NA slants. The flasks were kept on shaker conditions of $600 \mathrm{rpm}$ for $48 \mathrm{hr}$ at $30^{\circ} \mathrm{C}$ with media $\mathrm{pH}$ of 7.0 (Gupta et al., 2005; Patel et al., 1985).

\section{Production of Pectinase using Dry Mixed Kitchen Waste}

In $500 \mathrm{ml}$ Erlenmeyer flasks, 200g of crushed mixed dry kitchen waste was added and was dispensed with $100 \mathrm{ml}$ of D/W. To this flask, $10 \mathrm{ml}$ of bacterial suspension of O.D. 0.05 from inoculum flask was added. Similar set up was followed for studying the effect of temperature $\left(30^{\circ} \mathrm{C}\right.$ to $\left.60^{\circ} \mathrm{C}\right), \mathrm{pH}(6$ to 8 ) and concentration of vegetable waste ( $50 \mathrm{~g}$ to $300 \mathrm{~g}$ ) on enzyme production. The flask was incubated on a shaker at 400rpm for $48 \mathrm{hr}$. The supernatant was removed from the cultural broth by centrifuging it at 8000 rpm for $20 \mathrm{~min}$ and the clear filtrate was used for determining protease activity. $C_{x}$ ratio was calculated according to the following formula.(Gupta et al, 2005 and Patel et al., 1985).

$C_{\mathrm{x}}$ Ratio $=[($ Diameter of zone of clearance $) /$ (Diameter of Colony)].

\section{Protease Activity Measurement}

The enzyme was assayed in the reaction mixture containing $2.0 \mathrm{ml}$ of $0.5 \%$ casein solution in $0.1 \mathrm{M} \mathrm{CO} 3-\mathrm{HCO} 3$ buffer $(\mathrm{pH}$ 
9.5) and $1 \mathrm{ml}$ enzyme solution in a total volume of $3.0 \mathrm{ml}$. After inoculation at $30^{\circ} \mathrm{C}$ for five minutes, the reaction was stopped by adding of $3.0 \mathrm{ml}$ of $10 \%$ ice cold TCA and centrifuged at 10,000 rpm for five minutes. Protein in the supernatant was estimated by the method of Lowry et al. (Patel et al., 1985; Sabota et al., 1995).

\section{Results and Discussion}

Eight isolates showing protease activity were obtained based on zones of clearance seen around them. The three isolates showing good $\mathrm{C}_{\mathrm{x}}$ ratio on agar plate were selected from 8 isolates, of which 3 isolates showing maximum $C_{x}$ ratio were than selected and were named DSP 1, DSP 2 and DSP 3 (Table 1 and Fig 1,2).

Based on their enzyme activity study, out of three isolates, only one (DSP2) was finalized for further studies. Morphological and Biochemical studies of the culture DSP2 was also done. This culture was found to be Gram negative in nature. Biochemically the culture of DSP2 was found to be belonging to the Bacillus group of sp.16S rRNA gene was amplified and sequencing of partial sequence of $980 \mathrm{bp}$ was carried out. Using BLAST analysis, the organism was found to be Bacillus sp. which was incorporated in to the collaborative nucleotide database of GenBank, EMBL and DDBJ and assigned an accession number (Table1).

The temperature and $\mathrm{pH}$ of the cultivation medium are important factors in the protease production, which may influence the sort and content of those enzymes produced by filamentous fungus and bacteria (Sabota $e t$ al.,1995; Suseela R, 1998; Ogrydziak et al., 1998).The strong effect of $\mathrm{pH}$ on the production of protease was clearly observed in flask cultures, where $\mathrm{pH}$ value 6-8, and temperature $30^{\circ} \mathrm{C}-50^{\circ} \mathrm{C}$ were tested for crude enzyme production (Fig 3,4,5). The maximum pectinase activity was found with an initial $\mathrm{pH}$ of 6 at temperature $30^{\circ} \mathrm{C}$, activity reaching $0.69 \mu \mathrm{g} / \mathrm{ml} / \mathrm{min}$ on fifth day of incubation. When the temperature was maintained at $40^{\circ} \mathrm{C}$ and $50^{\circ} \mathrm{C}$ with $\mathrm{pH} 6$, the enzyme activity was found to be 0.51 $\mu \mathrm{g} / \mathrm{ml} / \mathrm{min}$ and $0.46 \mu \mathrm{g} / \mathrm{ml} / \mathrm{min}$ respectively on fifth day of incubation. By keeping the $\mathrm{pH}$ constant at $\mathrm{pH} 7$, the enzyme activity was measured as $0.57 \mu \mathrm{g} / \mathrm{ml} / \mathrm{min}$ at $30^{\circ} \mathrm{C}$, 0.504 at $40^{\circ} \mathrm{C}$ and $0.39 \mu \mathrm{g} / \mathrm{ml} / \mathrm{min}$ at $50^{\circ} \mathrm{C}$ whereas by keeping $\mathrm{pH} 8$ as constant, it was seen that the enzyme activity was found to be $0.61 \mu \mathrm{g} / \mathrm{ml} / \mathrm{min}$ at $30^{\circ} \mathrm{C}, 0.44 \mu \mathrm{g} / \mathrm{ml} / \mathrm{min}$ at $40^{\circ} \mathrm{C}$ and $0.33 \mu \mathrm{g} / \mathrm{ml} / \mathrm{min}$ at $50^{\circ} \mathrm{C}$. So optimum $\mathrm{pH}$ for enzyme production was found to be 6 and optimum temperature was found to be $30^{\circ} \mathrm{C}$. Either increase or decrease beyond the optimum value show decline in enzyme production. However, the mechanism by which the $\mathrm{pH}$ and temperature both acts on the same time for the production of protease enzyme is not clearly known.

The temperature optima of $30^{\circ} \mathrm{C}$, was obtained from a purified culture fluid of P.frequentans by Patel et al., 1985. This can give the support to our obtained result. From the observation it was clear that $30^{\circ} \mathrm{C}$ was the optimum temperature for the growth of microorganisms, variation was done in different $\mathrm{pH}$ and it was seen that $\mathrm{pH} 6$ was optimum (Fig 4, 5, 6).

Supplementation of different carbohydrate sources (dextrose, mannitol, sucrose and starch) to the production medium increase the protease activity of $D S P 2(\mathrm{Fig} 7,8)$. When $\mathrm{pH} 6$ and temperature $30^{\circ} \mathrm{C}$ (both optimum for production) were maintained constant in production medium, the different carbohydrate sources showed different effect on protease production respectively. 
Table.1 Cx Ratio and Enzyme Activity of the Final Three Pectinase Producing Isolates

\begin{tabular}{|c|c|c|c|}
\hline $\begin{array}{c}\text { Isolate } \\
\text { Name }\end{array}$ & GenBankAccn No & $\mathrm{C}_{\mathrm{x}}$ ratio & $\begin{array}{c}\text { Enzyme } \\
\text { activity } \mu \mathrm{g} / \mathrm{ml} / \mathrm{min}\end{array}$ \\
\hline DSP1 & ----- & 3.8 & 2.78 \\
\hline DSP2 & JN836944 & 4.2 & 4.89 \\
\hline DSP3 & ----- & 3.7 & 3.76 \\
\hline
\end{tabular}

Table.2 Morphological and Biochemical Characteristics of Isolated Bacillus sp.(dsp2)

\begin{tabular}{|c|c|}
\hline $\begin{array}{l}\text { Morphological, Cultural, Physiological and } \\
\text { Biochemical characteristics }\end{array}$ & Results \\
\hline \multicolumn{2}{|c|}{ Morphology } \\
\hline Cell shape & Rod \\
\hline Size & $5.25 \mu \mathrm{m}$ \\
\hline Gram's reaction & Gram negative \\
\hline Capsule & Present \\
\hline Spore & spore forming \\
\hline \multicolumn{2}{|c|}{ Cultural condition } \\
\hline Growth & Aerobic \\
\hline Motility & Motile \\
\hline Growth in $\mathrm{NaCl}(20 \%)$ & + \\
\hline Growth temperature $\left({ }^{\circ} \mathrm{C}\right)$ & $35-37$ \\
\hline \multicolumn{2}{|c|}{ Biochemical activities } \\
\hline Catalase & + \\
\hline Oxidase & - \\
\hline Glucose & Acid \\
\hline Sucrose & Acid/Gas \\
\hline Lactose & Acid \\
\hline Fructose & Acid \\
\hline Arabinose & Acid/Gas \\
\hline Galactose & Acid/Gas \\
\hline Mannitol & Acid \\
\hline Raffinose & Acid/Gas \\
\hline Xylose & Acid/Gas \\
\hline Methyl red & - \\
\hline VP-test & + \\
\hline Indole & - \\
\hline Citrate & - \\
\hline Nitrate & + \\
\hline Urease & + \\
\hline Casein Hydrolysis & + \\
\hline Starch & + \\
\hline Gelatin & + \\
\hline Identification (DSP2) & $\begin{array}{l}\text { Above characteristics indicates } \\
\text { that the isolate belongs to the } \\
\text { genus Bacillus gr }\end{array}$ \\
\hline
\end{tabular}


Fig.1 Comparison of Cx Ratio among Final Three Pectinase Producing Isolates

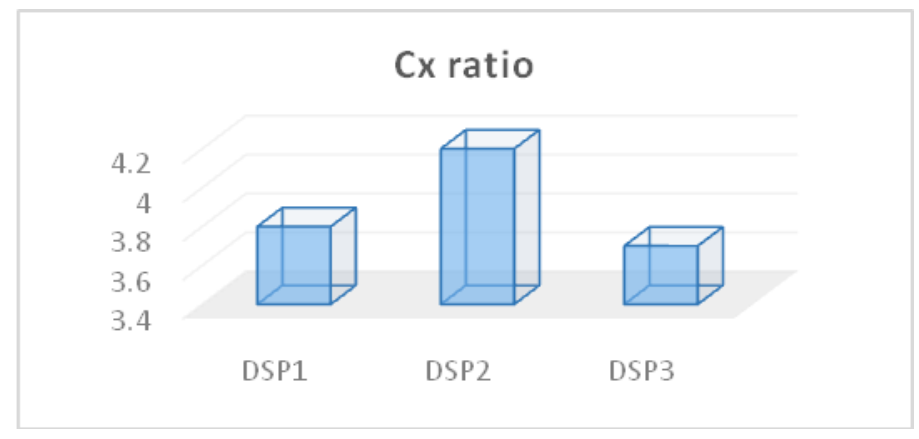

Fig.2 Comparison of Enzyme Activity among Final Three Pectinase Producing Isolates

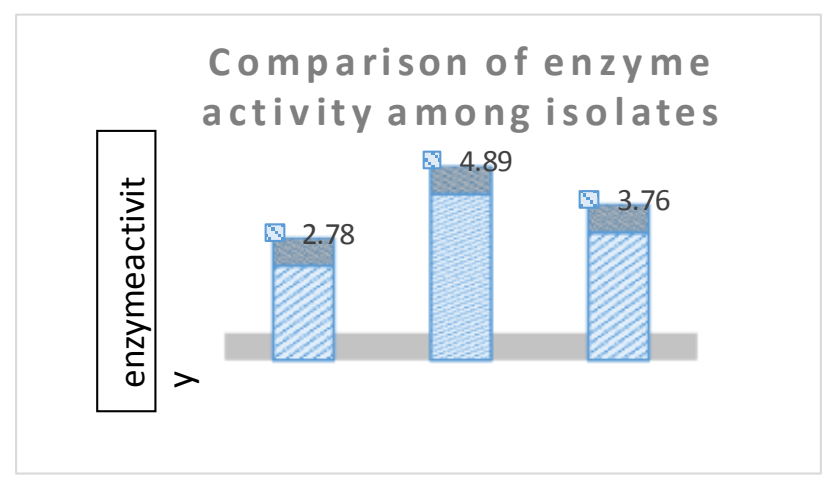

Fig.3 Gram Negative Bacillus Dsp2 (100x)

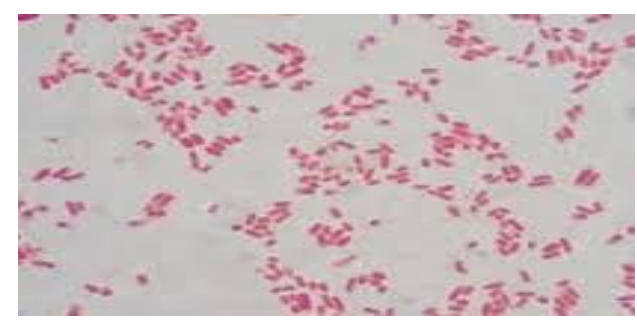

Fig.4 Enzyme Activity Measured at Different Temperatures Keeping pH 6

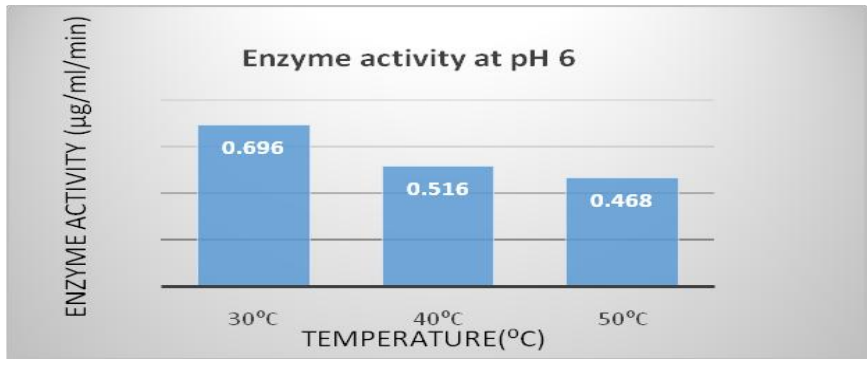


Fig.5 Enzyme Activity Measured at Different Temperatures Keeping pH 7

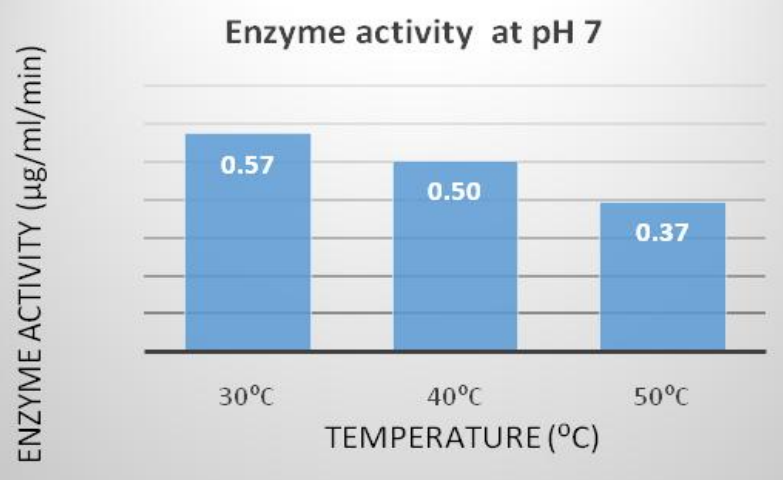

Fig.6 Enzyme Activity Measured at Different Temperatures Keeping pH 8

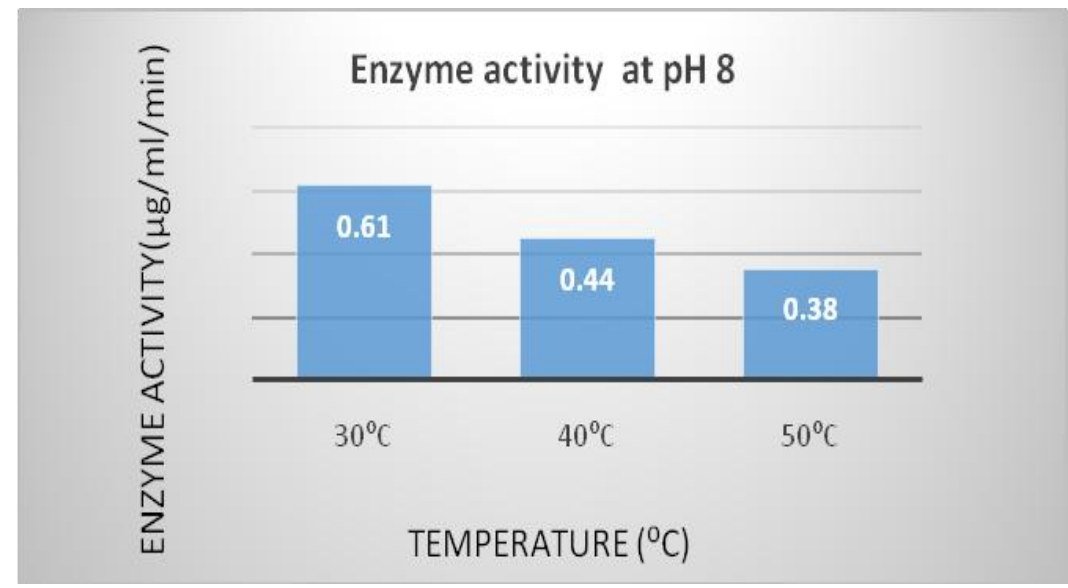

Fig.7 Graph to Show the Enzyme Activity with Different Carbohydrates

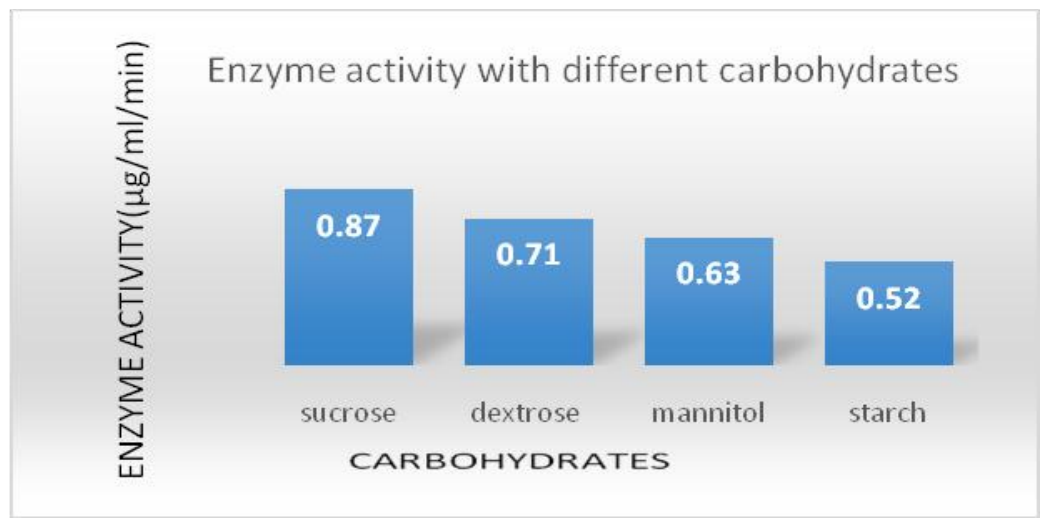


Fig.8 Graph to Show the Protein Concentration with Different Carbohydrates

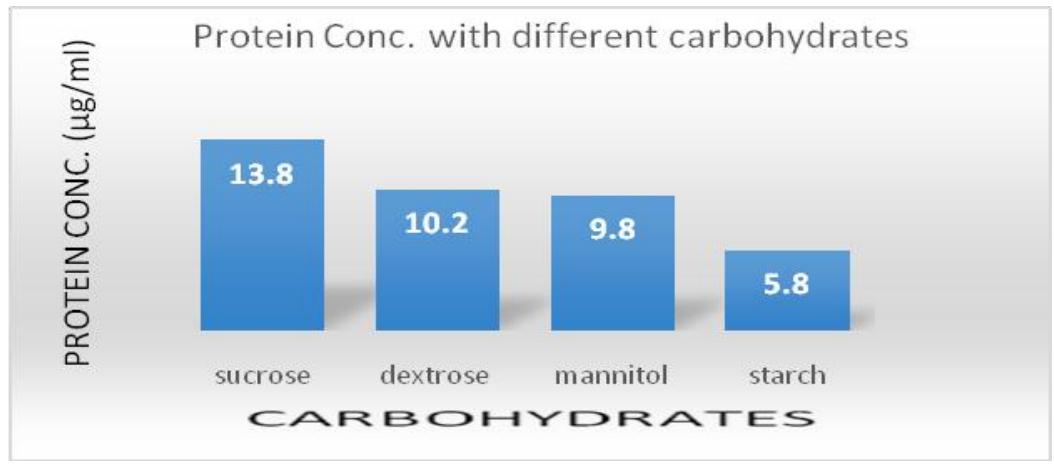

Fig.9 Graph Showing Enzyme Activity with Different Nitrogen Sources

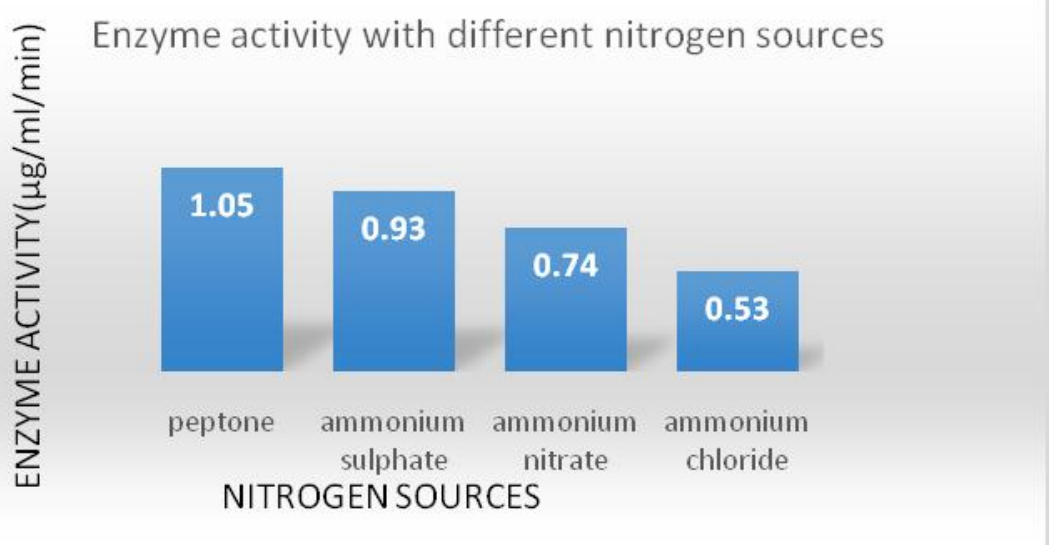

Fig.10 Graph Showing Protein Concentration with Different Nitrogen Sources

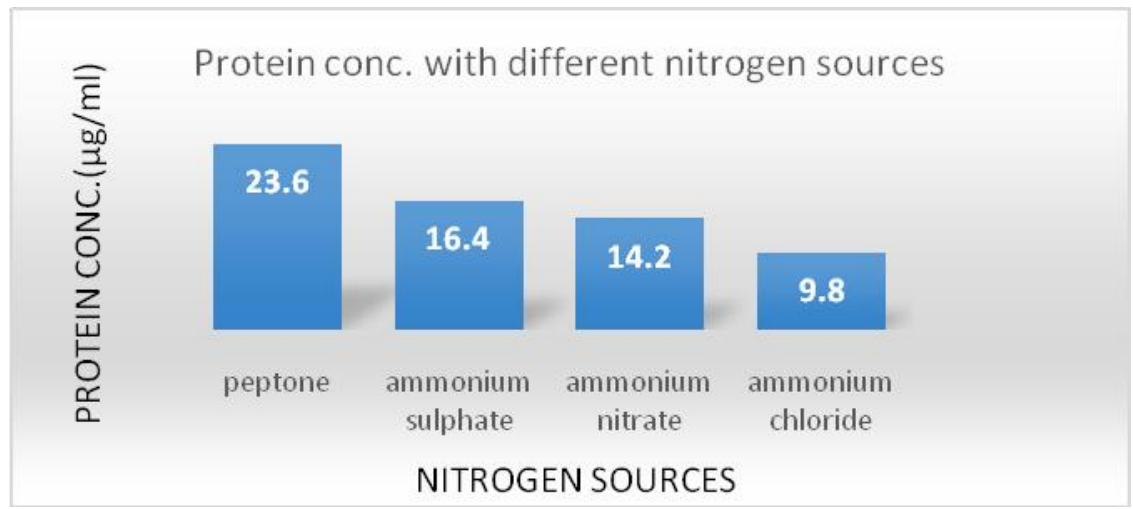


Fig.11 Enzyme activity after addition of various metals

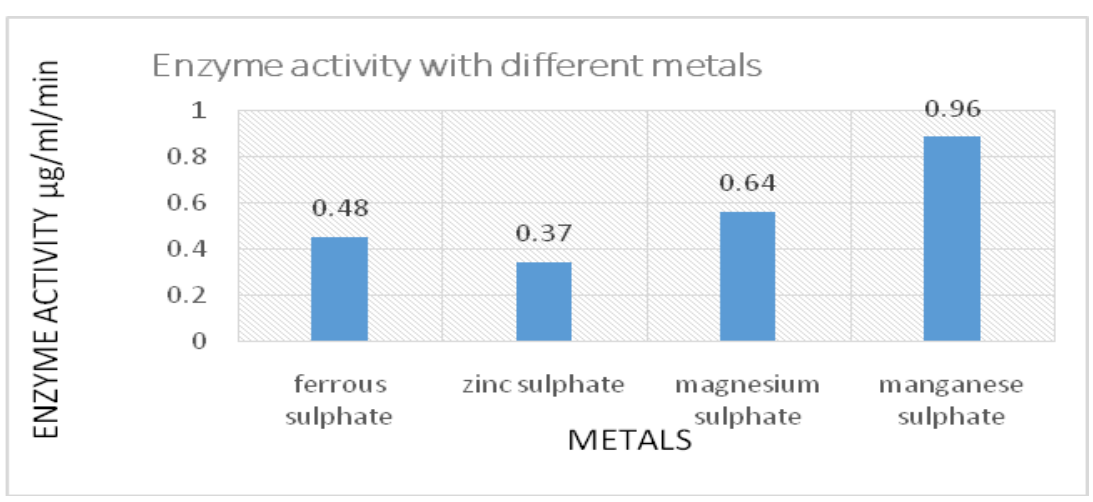

In presence of sucrose the crude production was maximum $(13.7 \mu \mathrm{g} / \mathrm{ml})$ and enzyme activity was found $0.876 \mu \mathrm{g} / \mathrm{ml} / \mathrm{min}$. In case of dextrose, mannitol and starch, the production was found $10.2 \mu \mathrm{g} / \mathrm{ml}, 9.7 \mu \mathrm{g} / \mathrm{ml}$ and $5.8 \mu \mathrm{g} / \mathrm{ml}$ respectively and enzyme activity was found $0.73 \mu \mathrm{g} / \mathrm{ml} / \mathrm{min}$, $0.63 \mu \mathrm{g} / \mathrm{ml} / \mathrm{min}$ and $0.51 \mu \mathrm{g} / \mathrm{ml} / \mathrm{min}$ respectively. So from our data it can be concluded that the protease production rate was highly repressed in presence of starch and highly induced for enzyme production in presence of sucrose. Kaur et al., 1998; Marzan et al., 2002 obtained significant protease production by growing P.griseorosum in medium containing 60-74 $\mu \mathrm{M}$ sucrose.

Of the different nitrogenous sources (ammonium sulphate, ammonium nitrate, ammonium chloride and peptone) used, peptone has enhanced the production of Bacillus $s p$ protease when medium optimum $\mathrm{pH}$ and temperature were 6 and $30^{\circ} \mathrm{C}$ respectively (Fig 9, 10). Sabota et al., 1995 and Matsushima et al., 1981, reported that peptone followed by ammonium sulphate stimulated protease production more, as in their absence bacteria displayed a slight proteolytic activity and did not produce extracellular protease.
Different metals (zinc sulphate, magnesium sulphate, manganese sulphate and ferrous sulphate) influenced on enzyme activity was also studied (Fig 11). Optimal activity was observed at $1 \mathrm{mg} / \mathrm{ml}$ of manganese sulphate $(0.88 \mu \mathrm{g} / \mathrm{mL} / \mathrm{min})$ and least activity was found in presence of $1 \mathrm{mg} / \mathrm{ml}$ of zinc sulphate $(0.34 \mu \mathrm{g} / \mathrm{mL} / \mathrm{min})$. It may be suggested that the active sight of protease was influenced by magnesium sulphate to catalyse the hydrolytic reactions and negative cooperativity was shown by zinc sulphate (Marzan et al., 1999 and 2002).

In conclusion, the present investigation reports a new, effective and easy method for obtaining protease producing organisms from vegetable kitchen wastes. Thus in future, similar cheaper sources such as carrot waste can be employed for the extraction of enzyme protease which holds numerous industrial applications.

\section{References}

Fermor, T.R., Wood, D.A. 1981. Degradation of bacteria by Agaricus bisporus and other fungi. Gen. Microbial, 126: 377-387.

Gupta, A., Roy, I., Patel, R.K., Singh, S.P., Khare, S.K., Gupta, M.N. 2005. One step purification and characterization of an alkaline protease from 
haloalkaliphilic Bacillus sp. J. Chromatogr., 1075: 103-108.

Kalisz, H.M., Moore, D., Wood, D.A. 1986. Protein utilization by basidiomycete fungi. Trans. Brit. Mycol. Soc., 86: 519-525.

Kaur, M., Dhillon, S., Chaudhary, K., Singh, R. 1998. Production, purification and characterization of a thermostable alkaline protease from Bacillus polymyxa. Ind. J. Microbiol., 38: 6367.

Marzan, L.W., Abdul Manchur, M.D., Towhid Hossain, M.D., Anwar, M.N. 1999. Isolation of protease producing fungi and their protease activity. The hittagong Univ. J. Sci., 23: 101-106.

Marzan, L.W., Abdul Manchur, M.D., Towhid Hossain, M.D., Anwar, M.N. 2002. Protease production by a strain Aspergillus funiculosus. Bangladesh $J$. Life Sci.

Matsushima, K., Hayakawa, M., Ito, M., Shimada, K. 1981. Features of the proteolytic enzyme system of hyperacid-productive and non-acidproductive fungi. J. Gen. Appl. Microbial., 27: 423-426.

Micales, J.A., 1992. Proteinases of the brown rot fungus Postia placenta. Mycologia, 84: 815-822.
Moon, S.H., Paruleker, S.J.A. 1991. parametric study of protease production in batch and fed-batch cultures of Bacillus firmus. Biotechnol. Bioengg., 37: 467-483.

Ogrydziak, D.M., Yamada, T. 1983. Extracellular acid proteases produced by Saccharomycopsis lipolytica. $J$. Bacteriol., 154: 23-31.

Patel, P.R. 1985. Enzyme isolation and purification. In: Biotechnology: Applications and Research Technomic Publishing Co. Inc., USA. 534-564.

Sabota, R.R., Rahman, M.M., Choudhury, N. 1995. Extra cellularproteolytic activity of Saccharomyces cerevisiae strain DSM 1848. Bangladesh J. Microbiol., 12: 45-49.

Sabota, R.R., Rahman, M.M., Choudhury, N. 1995. Extracellular proteolytic activity of Saccharomyces cerevisiae strain DSM 1848. Bangladesh J. Microbiol., 12: 45-49.

Suseela, R. 1998. Hyolysis of chrometanned leather waste and production of alkaline protease BBY A Penicillium species. International Symposium on Ecology of Fungi, Goa University, Goa-403 206, India.

\section{How to cite this article:}

Diptendu Sarkar and Goutam Paul. Extraction and Bio-chemical Characterization of Protease Enzyme from a Proteolytic bacteria Isolated from Dry Mixed Kitchen Waste. Int.J.Curr.Microbiol.App.Sci. 5(3): 268-276. doi: http://dx.doi.org/10.20546/ijcmas.2016.503.033 